УДК 351.83

DOI https://doi.org/10.32837/pyuv.v1i3(28).345

\author{
С. А. Савела \\ курсант факультету підготовки фахівиів \\ для органів досудового розслідування \\ Дніпропетровського державного університету внутрішніх справ
}

А.С. Ярошенко

кандидат юридичних наук,

доцент кафедри иивільного права та процесу

Дніпропетровського державного університету внутрішніх справ

\title{
ПИТАННЯ ІЕНДЕРНОЇ ПОЛІТИКИ В НАЦІОНАЛЬНІЙ ПОЛІЦІЇ УКРАЇНИ: ТЕОРЕТИКО-ПРАВОВИЙ АСПЕКТ
}

У ст. 24 Конституції України проголошено, що не може бути привілеїв чи обмежень за ознаками, зокрема за статтю. Рівність прав жінки і чоловіка забезпечується: наданням жінкам рівних із чоловіками можливостей у громадсько-політичній і культурній діяльності, у здобутті освіти і професійній підготовці, у праці та винагороді за неї; спеціальними заходами щодо охорони праці і здоров'я жінок, встановленням пенсійних пільг; створенням умов, які дають жінкам можливість поєднувати працю з материнством; правовим захистом, матеріальною і моральною підтримкою материнства i дитинства, включаючи надання оплачуваних відпусток та інших пільг вагітним жінкам і матерям [1]. На даному етапі розвитку українського суспільства питання становлення ґендерного паритету як напряму державної політики є одним із пріоритетних завдань, не лише результатом трансформаційних процесів світосприйняття соціуму, а й курсом України на встановлення стійких міжнародних зв'язків. Основною метою державної політики є не просто окреслення та вивчення питання ґендерної стратифікації, а й розроблення відповідних заходів подолання таких проблем. Особливої актуальності питання гендерної паритетності набуває в межах трудового поля, а саме під час реалізації жінками свого права на працю в деяких сферах життєдіяльності, зокрема в системі Міністерства внутрішніх справ України.

Мета статті - встановлення гендерної проблематики в сучасному суспільстві та формування основних положень щодо вирішення питання гендерної паритетності в органах Національної поліції України. Поставлена мета зумовила виконання таких завдань:

- вивчення й аналіз питання ґендерного паритету у правоохоронних органах України;

- вивчення трудового законодавства України щодо становища жінки-поліцейської й окремих міжвідомчих нормативних актів Міністерства внутрішніх справ України;
- надання теоретичних пропозицій щодо вирішення проблеми гендерного розподілу у правоохоронній сфері.

Питання ґендерної стратифікації, а також окремі питання, що стосуються цієї проблематики, вивчали такі науковці, як: Ю. Антонян, О. Бандурка, В. Батиргареєва, О. Бінецька, Л. Гаухман, Я. Гілінський, В. Голіна, І. Даньшин, С. Лешанич, Л. Козуб, Л. Ковальчук, Л. Кормич, А. Політова, О. Свердлова, Р. Шелудяков та ін.

Стрімке перетворення суспільних відносин у сучасному світі характеризується підвищенням ролі жінки у становленні окремих життєво важливих соціальних сфер, а також відносин на основі цього явища із чоловічою частиною соціуму, сприйняттям жінки в певних колах тощо. Проблема рівності чоловіка та жінки не є чимось новим для будь-якої світової держави, адже вона мала місце протягом становлення та розвитку суспільних зав'язків. В умовах сьогодення поступово починають руйнуватися стереотипи стосовно уявлення про становище жінки і чоловіка в суспільстві. Зокрема, усе більший відсоток жінок обіймають посади у правоохоронних органах та інших воєнізованих організаціях. Однак усе ще невирішеною залишається проблема зміни світосприйняття українським суспільством щодо реальних можливостей жінки, якою, на нашу думку, повинна займатися держава. В українському суспільстві, як і в інших державах світу, чітко простежується гендерна стратифікація, яка знаходить свій вияв навіть у самій гендерній дискримінації. «У першу чергу це стосується всіх рівнів системи управління. Адже саме тут приймаються рішення, які обумовлюють стратегію і тактику розвитку. I паритетне представництво жінок i чоловіків є неодмінною умовою ефективності результату діяльності. Однак на керівному рівні, наприклад, серед державних службовців 1-3 рангів, жінки становлять абсолютну меншість - від 6 до $12 \%$, тоді як на виконавчому рівні фахівців, у нижчих категоріях їх частка в окремих сферах 
сягає 82-88\%. А це означає, що реального впливу на процес прийняття рішень жінки не мають. Це стосується не лише виконавчої, а і представницької, законодавчої влади різних рівнів, де на вищих щаблях жіноче представництво обмежене $8-10 \%$ » [2, с. 19$]$.

Відповідно до Закону України «Про забезпечення рівних прав та можливостей жінок і чоловіків», метою діяльності органів державної влади України є досягнення паритетного становища жінок і чоловіків у всіх сферах життєдіяльності суспільства шляхом правового забезпечення рівних прав та можливостей жінок і чоловіків, ліквідації дискримінації за ознакою статі та застосування спеціальних тимчасових заходів, спрямованих на усунення дисбалансу між можливостями жінок і чоловіків реалізовувати рівні права, надані їм Конституцією і законами України [3]. Упровадження ґендерної політики на засадах принципу рівності прав та можливостей жінки і чоловіка є основою побудови демократії. Однак, незважаючи на це, спостерігається нестабільність у відносинах чоловіків і жінок, особливо у сфері трудових відносин, зокрема у правоохоронній структурі, що традиційно вважається «чоловічою роботою». Гендерна політика як напрям державної діяльності, спрямований на реальне утвердження рівних прав і забезпечення рівних можливостей осіб обох статей через надання гарантій рівної участі в усіх сферах публічного життя, створення збалансованої системи пільг і соціального захисту для жінок і чоловіків, забезпечення рівних можливостей на ринку праці, у сфері освіти тощо, потребує подальшого теоретичного обгрунтування» [4]. Неможливо сказати, що всі заходи, які намагалися впроваджувати органи державної влади, не мали жодного результату, адже зараз жінки працюють у багатьох воєнізованих структурах.

В Україні спостерігається тенденція до збільшення кількості жінок, які працюють на різних посадах в органах Національної поліції. Однак, незважаючи на значну кількість жінок-правоохоронців, їхня роль усе ще залишається неприйнятною для чоловіків, які працюють у силовій сфері. Адже вони вказують на малозначність жінок у поліції, на відсутність у них таких навичок і вмінь, як у чоловіків тощо. Так, дуже часто вказують на їхню біологічну функцію дітонародження, говорячи про те, що жінка рано чи пізно піде в декретну відпустку, тому немає сенсу в її працевлаштуванні. Такі дії, ми переконані, є одним із проявів дискримінації за ознакою статі під час прийняття жінок на роботу.

Така стратифікація простежується вже під час добору на навчання до спеціалізованих закладів Міністерства внутрішніх справ (далі - МВС), коли визначається конкретна кількість місць для жінок і чоловіків, тобто проводиться певна кількіс- но-ґендерна межа. Що ж стосується України, то до 1999 р. кількість жінок у правоохоронних органах була обмежена, наприклад, так звана «жіноча» квота до вступу до навчальних закладів МBC становила 5-10\% [5]. Такі дії, беззаперечно, можна називати ґендерною дискримінацією. Однак відзначаємо, що сьогодні жінки, які навчаються в закладах зі специфічними умовами навчання, уже не така рідкість, навпаки, багато дівчат вступають до вишів із метою працювати в майбутньому в лавах поліції.

Так, за даними Національної поліції України, кількість жінок в органах та підрозділах служби цивільного захисту становить $12,5 \%$ загальної чисельності, в апараті Державної служби України 3 надзвичайних ситуацій (далі - ДСНС) - 47,2\% . У Держприкордонсужбі $24 \%$ особового складу - жінки, з яких 13\% - офіцери. У структурі Національної поліції працюють 21,8\% жінок. Відсоткове співвідношення кількості військовослужбовців-жінок у Нацгвардії до кількості військовослужбовців-чоловіків становить 6,2\% [6].

У поліції жінки здебільшого виконують паперову роботу, з огляду на їхні фізіологічні та психологічні дані, однак є невеликий відсоток жінок, які залучені до виконання спеціальних завдань, залучаються до проведення спеціальних операцій. Зокрема, європейські правоохоронці стверджують, що служба жінки в поліції є дуже результативною. Так, жінки більш комунікабельні, тому під час урегулювання сімейних конфліктів, зокрема і домашнього насильства, роль жінки незамінна. Жінки набагато краще складають іспити й засвоюють матеріал у процесі навчання. Поліцейських-жінок намагаються не залучати до роботи з агресивними правопорушниками, звільнення заручників, роботи у спецпідрозділах, але під час підготовки жінки-поліцейські та чоловіки проходять однаковий курс навчання, їхні знання, навички і якості оцінюють за однаковими критеріями [7, с. 132].

У вітчизняних правоохоронних органах, незважаючи на те, що праця жінки в поліції має багато переваг, роль жінки-керівника намагаються не розглядати, керуючись усталеними стереотипами, що керівником, у силових структурах і поготів, може бути лише сильний і мужній чоловік. Жінці, щоб обійняти керівну посаду, необхідно докласти набагато більше зусиль, аніж чоловікові. Варто наголосити, що в поліції і дотепер немає жодної жінки-генерала.

Водночас також варто зазначити, що окремі аспекти у правоохоронних органах підлаштовані саме під чоловіків, ставлячи жінку-поліцейського в особливо незручне становище, адже жінки стикаються з багатьма перешкодами. Так, однією з перешкод є невідповідні обладнання й уніформа жінок-поліцейських за розмірами. Зокрема, 
під час підготовки правоохоронців до використання прийомів самозахисту, затримання злочинців жінок і чоловіків готують за однією програмою, незважаючи на фізичні особливості осіб жіночої статі (зріст, вага), що робить їх більш уразливими під час виконання практичних завдань. У цьому ж контексті ми говоримо і про єдині вимоги щодо складання фізичних іспитів під час вступу до закладів зі специфічними умовами навчання, що $€$ перешкодою для жінок. I до сьогодні залишається проблема сприйняття жінки на роботі як сексуального об’єкта, а не звичайного працівника. Особливо актуальне питання трудового законодавства для жінок-правоохоронців.

Так, ні для кого не буде новиною, що під час добору на службу в поліції до жінок висувається низка питань стосовно поєднання служби та домашніх обов'язків. Не менш проблемним для роботодавців здається питання поєднання репродуктивної функції жінки, використання декретної відпустки та виконання обов'язків жінкою на посаді поліцейського. Крім того, чимало керівників говорять про те, що гендерна рівність - рівність не лише у правах, а й в обов'язках. Однак ми не згодні з такими твердженнями. Так, справді, ґендер - рівність прав, наданих жінці та чоловікові в однаковому обсязі, рівність їхніх можливостей щодо реалізації себе в усіх сферах життєдіяльності, однак недаремно на законодавчому рівні встановлені дещо різні вимоги до чоловіків і жінок. Так, наприклад, жінку не зобов'язують до виконання військового обов'язку, жінці надаються пільги, пов' язані з вагітністю та пологами, жінок забороняється залучати до важких робіт, робіт у нічний час тощо. Говорячи про гендерну рівність, не можна нехтувати біологічними показниками, фізіологічними відмінностями жінки та чоловіка. Чоловік набагато сильніший і витриваліший, психологічно стійкіший, на відміну від жінки, що і розрізняє ці дві статі. Так, відповідно до ст. 3 Закону України «Про відпустки» [8], одним із видів відпусток є соціальна відпустка для догляду за дитиною до досягнення нею трирічного віку, і там не зазначено обмеження для окремих видів професій. Тобто виходить, що працювати в органах поліції та паралельно набути статусу «матері» цілком законно.

Крім того, у Законі України «Про забезпечення рівних прав та можливостей жінок і чоловіків» установлено, що обов'язок керівника полягає в забезпеченні жінкам і чоловікам можливості суміщати трудову діяльність із сімейними обов'язками; уживати заходів щодо унеможливлення випадків сексуальних домагань, для створення безпечних для життя і здоров'я умов праці [3].

Щодо трудового законодавства, то за загальним правилом, згідно з Кодексом законів про працю (далі - КЗпП) України, визначено, що законодавство про працю складається із КЗпП України й інших законодавчих актів, ухвалених відповідно до нього [9]. На підставі цього положення сумнівним є віднесення спеціального закону до актів власне трудового законодавства. Закон України «Про Національну поліцію» містить норми трудового права, однак не є власне трудовим. Отже, у трудовому полі Закон України «Про Наці ональну поліцію» має субсидіарний характер, а трудові відносини регулює КЗПП України. Саме через це апелювати до того, що служба в поліції є спеціальним видом трудових відносин, які регулюються Законом України «Про Національну поліцію» та міжвідомчими нормативними актами, $€$ хибним шляхом.

Багато положень КЗпП і окремих законів України містять спеціальні норми, які регулюють працю жінок. Так, ст. ст. 175-186 КЗпП України встановлено обмеження праці жінок на роботах у нічний час, пільги для вагітних жінок і жінок, які мають дітей, відпустки у зв'язку з вагітністю та пологами і для догляду за дитиною, перерви для годування дитини, гарантії під час прийняття на роботу та заборону звільнення вагітних жінок і жінок, які мають дітей. Зокрема, згідно зі ст. 56 КЗпП, власник або уповноважений ним орган на прохання вагітної жінки, жінки, яка має дитину віком до чотирнадцяти років або дитину-інваліда, зокрема таку, що перебуває під її опікуванням, або здійснює догляд за хворим членом сім'ї відповідно до медичного висновку, зобов'язаний встановлювати їй неповний робочий день або неповний робочий тиждень [9]. У реальних умовах навіть найменша частина правових положень щодо праці жінки здебільшого не виконується, аргументується це тим, що служба в поліції є специфічним видом трудової діяльності. Крім того, частіше за все жінки чують вислів на кшталт того, що поліцейський - особа без статі, отже, які можуть бути привілеї за ознакою статі?!

У підсумку варто зазначити, що в нашій державі все ще залишається проблема гендерної стратифікації, не виняток і система Національної поліції України, де попри збільшення кількості жіночих кадрів, їхня роль усе ще залишається неприйнятною для чоловіків, які працюють у силовій структурі. Адже вони вказують на малозначність жінок у поліції, на відсутність у них таких навичок і вмінь, як у чоловіків тощо.

Зокрема, проблемою під час прийняття на службу в поліції є упереджене ставлення до жінки з боку керівника, який вказує їй на репродуктивну функцію, суміщення роботи та сімейних обов'язків, подальші складнощі з їі декретною відпусткою тощо, що є прямим проявом дискримінації за ознакою статі.

3 огляду на визначену проблематику, ураховуючи, що питання гендерної стратифікації чітко 
простежується у правоохоронних органах, пропонуємо з метою реалізації положень Конвенції Ради Європи «Про запобігання насильству над жінками та домашнього насильства і боротьбу з цими явищами», Закону України «Про забезпечення рівних прав та можливостей жінок і чоловіків» доповнити ст. 3 «Обов' язки керівника щодо підлеглих» Закону України «Про Дисциплінарний статут Національної поліції України» п. 9 у такій редакції: «Сприяти недопущенню проявів гендерної дискримінації під час виконання службових обов'язків підлеглими, а в разі виявлення таких дій ужити заходів для припинення такого порушення та застосувати дисциплінарне стягнення до порушника або порушити клопотання про застосування стягнення уповноваженим керівником». Зокрема, доповнити зазначений Закон положенням «Про дисциплінарну відповідальність керівника за дії, пов'язані із проявами гендерної нетерпимості та дискримінації за ознакою статі, а також обмеження прав жінок, пов'язаних з їхньою репродуктивною функцією». Також для запобігання неправильному трактуванню трудового законодавства з боку керівників доповнити статті Кодексу законів про працю України, які стосуються праці жінок, положенням у редакції: «У тому числі жінки, які працюють на посадах у правоохоронний органах України».

\section{Jimepamypa}

1. Конституція України : Закон України від 28 червня 1996 р. № $254 \mathrm{\kappa} / 96$-BP. URL: https://zakon.rada.gov.ua/ laws/show $/ 254 \%$ D0 $\%$ BA $/ 96-\%$ D0 $\%$ B2 $\%$ D1 $\% 80$ (дата звернення: 03.12.2019).

2. Кормич Л. Гендерні відносини: сутність та значення в суспільно-політичному розвитку. Актуальні проблели політики. 2013. Вип. 49. С. 16-22.

3. Про забезпечення рівних прав та можливостей жінок і чоловіків : Закон України від 8 вересня 2005 p. № 52. URL: https://zakon.rada.gov.ua/laws/show/286615/ed20050908 (дата звернення: 04.12.2019).

4. Бінецька О. Гендерна політика в Україні: загальна характеристика становлення. URL: http://intkonf.org/binetska-ov-genderna-politikav-ukrayini-zagalna-harakteristika-stanovlennya/ (дата звернення: 05.12.2019).

5. Свердлова O. Жінки в поліції. URL: http://noborders.org.ua/zhinki-v-politsiyi/ (дата звернення: 05.12.2019).

6. Нацполіція порахувала жінок у своїх лавах. URL: https://www.ukrinform.ua/rubric-society/2343352nacpolicia-porahuvala-zinok-u-svoih-lavah.html (дата звернення: 05.12.2019).

7. Політова А. Права жінок-поліцейських та політика гендерної рівності: досвід інших країн у вітчизняному контексті. Національна поліщія Донеччини: проблели становлення та стратегія розвитку : тези доповідей Всеукраїнської науково-практичної конференції, м. Маріуполь, 21 жовтня 2016 р. ДВНЗ «ПДТУ» ; Головне упр. Нац. поліції в Донецькій області ; Донецькій юридичний ін-т. Маріуполь, 2016. С. 132-134.

8. Про відпустки : Закон України від 15 листопада 1996 p. № 504/96-BP. URL: https://zakon.rada.gov. ua/laws/show/504/96- \% D0 \% B2\% D1\% 80/ed20100330 (дата звернення: 07.12.2019).

9. Кодекс законів про працю України : Закон України від 10 грудня 1971 р. № 322-VIII. URL: https://zakon.rada.gov.ua/laws/show/322-08 (дата звернення: 08.12.2019).

\section{Анотація}

Савела С. А., Ярошенко А. С. Питання гендерної політики в Національній поліції України: теоретикоправовий аспект. - Стаття.

Під час написання наукової статті було поставлено за мету проведення аналізу гендерної проблематики в сучасному суспільстві, формування основних положень щодо вирішення питання ґендерної паритетності в органах Національної поліції України шляхом вивчення трудового законодавства України щодо становища жінки-поліцейської й окремих міжвідомчих нормативних актів Міністерства внутрішніх справ України, аналізу статистичних даних на теперішній час. Так, у статті нами були розглянуті окремі аспекти актуальної проблеми в українському соціумі - гендерного паритету. Зокрема, було детально проаналізовано питання наявності гендерної дискримінації в органах Національної поліції України та правоохоронних органах загалом. Нами були визначені основні шляхи виникнення ґендерної стратифікації. Також у процесі написання наукової статті нами були розглянуті окремі положення Кодексу законів про працю України, що стосуються праці жінок, і проведений аналіз реального становища жінки в Національній поліції України, запропоновані шляхи усунення наявних і можливих проявів гендерної дискримінації. У процесі нашого дослідження щодо окресленої проблематики нами зроблені грунтовні висновки, надані пропозиції щодо іï вирішення. Так, зокрема, запропоновано внести зміни до Закону України «Про дисциплінарний статут Національної поліції» стосовно обов'язку керівника щодо підлеглих, а також доповнити зазначений Закон положенням «Про дисциплінарну відповідальність керівника за дії, пов'язані із проявами гендерної нетерпимості та дискримінації за ознакою статі, а також обмеження прав жінок, пов'язаних з їхньою репродуктивною функцією». Запропоновано викласти статті Кодексу законів про працю України, що стосуються праці жінок, зокрема щодо жінок, які працюють на посадах у правоохоронних органах України, у новій редакції.

Ключові слова: гендерний паритет, жінка, правоохоронні органи України, стратифікація, трудове законодавство.

\section{Summary}

Savela Ye. A., Yaroshenko A. S. The issue of gender policy in the National Police of Ukraine: theoreticallegal aspect. - Article.

During the writing of the scientific article, the aim was to analyze gender issues in modern society and to formulate basic provisions for addressing gender parity in the bodies of the National Police of Ukraine, by examining the labor legislation of Ukraine, the situation of women police officers and certain interagency normative acts of the Ministry of Internal Affairs of Ukraine, and analyzing statistics to date. Thus, in the article we considered some aspects concerning the current problem in the Ukrainian society, gender parity. In particular, the issue of gender discrimination in the bodies of the $\mathrm{Na}$ tional Police of Ukraine and law enforcement bodies in general was analyzed. We identified the main pathways 
for gender stratification. Also, when writing a scientific article, we considered the specific provisions of the Labor Code of Ukraine relating to women's work, and conducted an analysis of the real situation of women in the National Police of Ukraine and suggested ways to improve the existing and possible manifestations of gender discrimination. In the course of our research, on the outlined issues, we have made sound conclusions and suggested solutions. In particular, we were asked to amend the Law of Ukraine "On the Disciplinary Statute of the National Police" regarding the duty of the head in relation to subordinates, as well as to supplement the specified law with the provision "On the disciplinary responsibility of the head for actions related to manifestations of gender intolerance and discrimination by gender, as well as restrictions on women's rights related to their reproductive function", which are manifested. It was proposed to set out the articles of the Labor Code of Ukraine concerning women's labor, including those concerning women working for positions in the Ukrainian law enforcement agencies in the new version.

Key words: gender parity, woman, law enforcement agencies of Ukraine, stratification, labor law. 